Павле Павловић

Универзитет Сингидунум

ppavlovic@singidunum.ac.rs

https://doi.org/10.18485/ai_gozik.2019.ch13

$82.09 " 19 "$

14 Платон

\title{
ПАМЋЕЊЕ ЖАНРА СИМПОСИОНА У РОМАНУ ДЕВЕТНАЕСТОГ ВЕКА
}

Рад се бави наслеђем симпосиона у роману деветнаестог века. Главна теза је да се у симпосиону одређује позиција тела у односу на свет Другога. Као основ за анализу узимамо текст Платонове Гозбе и Бахтинов концепт „памћења жанра“. У Платоновом Симпосиону релативизује се одступање од две врсте правила: од правила за „озбиљну“ беседу и правила која се односе на предвидиви редослед догађаја. Комбинацијом ове две врсте одступања успоставља се позиција тела у односу на свет материје и свет Другога. Позиционирање тела у свету материје дефинишемо као бурлеску, а амбивалентно позиционирање - између света материје и света Другог - као гротеску. У светлу ових разматрања, анализирамо гозбене слике из Балзаковог романа Шагринска кожа, романа Достојевског Злочин и казна, Идиот и Гогољевих Мртвих душа.

Кључне речи: симпосион, деветнаести век, пијанство, роман, беседа, хармонија, позиција тела у свету.

\section{1. Уводна разматрања}

У роману 19. века гозбене слике откривају начин на који се позиција тела у свету конституише на основу сложених контекстуалних односа између представе о 
беседи и представе о поретку догађаја. У Платоновом Симпозиону беседа о гозби је много чвршће повезана са поретком догађаја. Аристодем приповеда о томе да је срео Сократа и да су се запутили Агатоновом дому пошто су чули да трагички песник прославља своју победу. Та „успутна“ беседа о гозби је подједнако битна као и беседе учесника на гозби, што се често заборавља када се говори о Платоновој Симпозионуи.

Гозбене слике откривају начин на који се позиција тела у свету конституише на основу сложених контекстуалних односа између представе о беседи и поретку догађаја. Под беседом овде подразумевамо: беседу изговорену на гозби и беседу о гозби, а као најважније догађаје узимамо долазак гостију на симпозион, упад пијанца или потпуни скандал - укратко, занима нас онај поредак догађаја на основу којих се симпозион одређује као успео или неуспео. Тек када све то узмемо у обзир, имаћемо ближу представу не само о томе шта нам Сократ говори него и шта нам цео симпозион говори о односу између духа и тела. На основу тога донећемо закључке о томе какву филозофску поруку шаљу гозбене слике у роману 19. века.

Беседа о гозби се јавља у разним облицима и на различите начине се односи према равни догађаја. У Лукијановој менипској сатири Битка Лабита и Кентаура беседу о гозби представљају ауторови иронични коментари о симпозиону епикурејаца, догађај се отео контроли и претворио у потпуни хаос. Као и Плутархова беседа, и та беседа дистанцирана је у односу на раван догађаја на симпозиону, само на потпуно други начин. Док је код Плутарха ова дистанца дискурзивне природе, дотле код Лукијана она има карактер тропа - ироније.

Поредак догађаја треба да сведочи о томе да ли је домаћин симпозиона гозби одржао ниво пристојности. 
У већини случајева догађаји који стварају хаос везују се за феномен пијанства, комоса и представу о умерености и неумерености. Догађаји на комосу могу бити безазлени (као што је, на пример, долазак Алкибијада на Агатонову гозбу, али исто тако могу садржати елементе насиља (као долазак Филоклеона са симпозиона приказан у Аристофановим Зољама). ${ }^{1}$

Укратко, комос у сваком тренутку може, али и не мора, да се претвори у низ хаотичних догађаја. Ове наративне и метанаративне, као и дискурзивне и метадискурзивне, елементе можемо наћи и у другим уметничким делима, али специфичност жанра симпозиона јесте у томе што он беседу о телу и догађаје на којима тело игра битну улогу доводи у везу са позицијом тела у свету духа и свету материје. Гозба, по дефиницији, претпоставља то да учесници имају свест о материјалном и духовном контексту свог телесног присуства. Беседа $о$ нечему, с друге стране, претпоставља смисао за апстракцију и у овом случају, у већој или мањој мери, подразумева дистанцу како у односу на текуће догађаје тако и у односу на властите физиолошке потребе.

У гозбеним сликама позиција тела у свету изграђује на основу суптилних контекстуалних односа између гозбене беседе и гозбеног догађаја. У гозбене беседе спадају беседе на гозби и беседе о гозби. Прву чине беседе коју изговарају учесници гозбе, а другу беседе и

1 О сликама комоса у Аристофановим комедијама видети: Bowie, A. M., Aristophanes: myth, ritual and comedy, Cambridge University Press, 1996; Bierl, A., „Komos and Comedy; B. Pütz: The Symposium and Komos in Aristophanes. (Drama: Beiträge zum antiken Drama und seiner Rezeption 22.) Pp. $x+306$, ills. Stuttgart and Weimar: Verlag JB Metzler, 2003. Paper, EUR39. 95. ISBN: 3-476-45318-9“, The Classical Review 55.2 (2005): 422; Bowie, A. M., „Thinking with drinking: wine and the symposium in Aristophanes", The Journal of Hellenic Studies 117 (1997): 1-21. 
извештаји о гозбама које су биле или који ће бити приређене. У гозбене догађаје спадају долазак на гозбу, ток гозбе и завршетак гозбе, који је обележен потпуним скандалом или новим упадом незваног госта, који прети да потпуно „поквари утисак“ о гозбеној хармонији.

Филозофска димензија беседе и филозофска димензија догађаја темеље се на представи о дозвољеном или предвидивом одступању од утврђених правила, које се испољава у разним нијансама гозбеног хумора: комичном димензијом говора и комичном димензијом догађаја. Главна тема Платонове Гозбе јесте однос између материје и духа који се контекстуализује идејом о љубави. Динамична природа тога односа огледа се не само у редоследу и садржају беседа него и у садржају и редоследу гозбених догађаја. ${ }^{2}$

Главни критеријум за ову поделу јесте однос између садржаја филозофске беседе, тела и догађаја на симпозиону. Да бисмо разумели оригиналност са којом поједини писци приказују гозбене слике, прво морамо прецизно одредити појмове гротеске и бурлеске. Под гротеском подразумевамо сваки идентитет између друштвене, телесне или језичке аномалије и вишег нивоа естетске игре, којом се успоставља један нови, алтернативни уметнички свет. За то су прави примери гозбене слике код Балзака, Гогоља и Достојевског. То што Семјон Мармеладов, у роману Злочин и казна (Преступление и наказание, 1866), као лакрдијаш (забављач) у најобичнијој крчми држи апокалиптичне беседе на архаичном руском језику, указује на једну вишу, егзистенцијалну димензију - димензију јеванђеоске проповеди и гротескног откровења. Лакрдијаш је

2 О вези између догађаја и беседа видети: Henderson, J., „The life and soul of the party: Plato, Symposium", Intratextuality: Greek and Roman Textual Relations (2000): 287-324. 
веома озбиљан. Према томе, тај несклад уведен је у име нечег другог, другог, бољег света - у име неке лепше и савршеније, рајске стварности. Алузијама на лакрдијашево неугледно тело само привидно се указује на то да оно припада свету материје. А у суштини, представа о неугледности говори о томе да је то тело издвојено од осталих тела у једном дубљем егзистенцијалном смислу. Своју скандалозну беседу оно изговара у име једног вишег принципа.

У гротески садржај односа између филозофске беседе и целокупног ситуационог контекста симпозиона задржава одређени ниво егзистенцијалне важности. У њој може постојати пародијско снижавање теме, као, на пример, у Аристофановој беседи, али гротескно тело о којем се говори, или на које се само алудира, има једно дубље значење. Према томе, беседа о гротескном телу или сама слика гротескног тела, за разлику од бурлеске, игра важну улогу у смисаоној организацији целокупне композиције симпозиона.

За разговоре пијанаца карактеристично је то да у њима доминира весели и радосни тон, који релативизује важност филозофске теме. Од тога у ком је степену тема релативизована, зависиће однос између трагичног и комичног карактера симпозиона. Ако је она превише релативизована, и не само то, него потпуно пародирана, онда је реч о бурлески. Лик прича толико бесмислено, неповезано и непристојно, да то нимало не доликује ни месту ни прилици. Он сам производи или говори о потпуном расулу.

С друге стране, ако Алкибијадов улазак најављује расуло, оно ипак представља очекивани део једне обредне и жанровске конвенције. У неким романима, као што је Идиот, јављају се ликови који, по својој улози, показују јасну сличност са Алкибијадом, као што је, на 
пример, Рогожин који упада на гозбу Настасје Филиповне. Лик паразита се не јавља у слици Тајферове гозбе. Разговори пијаних већ сами по себи представљају једну врсту расула, те, у случају поменуте гозбе, није потребно да се уводи нови елемент који нарушава хармонију симпозиона. Али те недвосмислене композиционе паралеле овде и нису толико важне. Суштина лежи у односу између хармоније и расула и гротескне уметничке логике помоћу које су та два елемента повезана. Ефекат бурлеске на симпозиону постиже се тако што се у питање доводи сагласје између теме беседе и карактера гозбеног догађаја. То ћемо подробно анализирати на примерима романа Ивана Нечуј-Левицког, Алека Константинова и Стевана Сремца.

У салонским разговорима потпуно се искључује могућност и гротеске и бурлеске. Разлог лежи у томе што статични идеал салонског космоса не трпи никакву нестабилност, већ се ослања на магију места, распореда и декорума. У већини случајева писци 19. века пародирају ове класицистичке конвенције, али не постижу обавезно бурлескни ефекат.

Дилема „логос или храна“, која постоји у Платоновом дијалогу, по правилу се решава у корист логоса, не обавезно филозофског, али свакако важног, посебног разговора или дијалога који се води између чланова друштвене елите. У свом најчистијем облику, примат говора над храном задржао се у британској књижевности, и разлоге за то треба тражити у „класицистичким“ конвенцијама викторијанске културе, која је практично обележила читаву британску књижевност 19. века, па чак и дела оних писаца као што је Оскар Вајлд, који су у сваком идеолошком смислу тражили отклон од викторијанства. У француској књижевности тешко је наћи „чисте примере“, будући да се у њој дух декорума 
редовно меша са више или мање притајеним испољавањем сексуалности, најчешће у гротескним контекстима. То исто важи и за руску књижевност, где се, по правилу, салонски догађаји пародирају као слике вештачке, отуђене француске културе. ${ }^{3}$

Главни параметри којима ћемо се служити јесу: композициона структура гозбе, однос између теме разговора и ситуације у којој се он води, и однос између трагичне и комичне димензије симпозиона. Овим параметрима служићемо се зато да бисмо оценили на који начин се односе хармонија гозбе и могућност њеног потпуног расула. Зато што управо на равнотежи сила реда и сила деструкције почива космос симпозиона.

Та равнотежа се може посматрати из неколико углова: као равнотежа између трагичног и комичног, као равнотежа између реда који успоставља домаћин и хаоса који производи паразит и као динамична равнотежа између теме и одступања од теме. О равнотежи између трагичног и комичног свој загонетан коментар дао је сам Платон, то јест Аристодем, главни Платонов приповедач: на крају гозбе једини будни остали су Агатон, Сократ и Аристофан, који пију заједно из једне чаше. Сократ Агатона и Аристофана убеђује у то да је прави песник онај који пише и комедије и трагедије $(223 \mathrm{~d})$. Дакле, и трагедија и комедија улазе у космос Платонове Гозбе. Међу говорницима су трагички и комички песник, а Дионис, који узима обличје Алкибијада, суди и једноме и другоме, управо на Великим дионизијама, које тек што су се завршиле. ${ }^{4}$ То што су,

3 Видети: Ames, K. L., Death in the dining room and other tales of Victorian culture, Temple University Press, 1995.

4 Видети: Sider, D., „Platos Symposium as Dionysian Festival“, Quaderni urbinati di cultura classica (1980): 41-56; Salman, C., „Anthropogony and Theogony in Plato's Symposium“, Classical Journal (1991): 214-225. 
на крају, и Агатон и Аристофан заспали, а филозофија, у обличју Сократа, остала будна, можда говори о томе да је управо филозоф онај који може писати и трагедију и комедију. Но, загонетна алузија на драмску уметност може значити и то да су доживљаји трагичног и доживљај комичног инхерентни људском бићу и да онај који најбоље познаје живот (а то је, опет, филозоф), најбоље познаје и може на најбољи начин писати у оба жанра. Сам Платон је писао трагедије, а сасвим је могуће да се окушао и у комедијама. Писац 19. века, као уметник гозбе, мора имати сличну врсту филозофске будности - мора бити не само уметник него и филозоф гротеске. Два највећа таква „филозофа“ јесу Балзак и Достојевски. Балзак је написао Људску комедију, али у тој комедији има много трагичних елемената. Исто важи и за Достојевског, премда је код њега трагична димензија много видљивија.

У композиционом смислу, динамична равнотежа симпозиона огледа се у равнотежи између реда који успоставља домаћин гозбе и уласка паразита. Алкибијадов улазак је очекиван, гротескан - он је ритуалне природе, и као такав, на гротескан начин доприноси рађању идеје о љубави. У тематском смислу динамична равнотежа се огледа у складу између теме беседе и привидном одступању од теме. Учесника симпозиона који одступа од теме на такав начин да његова упадица не представља никакву вербалну агресију нити неусаглашеност са општом атмосфером гозбе - можемо грубо назвати фигуром провокатора.

Тема Аристофанове беседе само појачава шаљиви тон који је већ присутан на симпозиону, што значи да између његових и Агатонових шала постоји једна динамична равнотежа. Међутим, ваља бити опрезан када се говори о могућем жанровском одређењу ове по- 
ставке. Није нам познато да је у жанру античког симпозиона постојала чврста, формална улога провокатора. Аристофанов испад могао би се донекле тумачити у контексту parrhesi-je, слободног говора, као једног од најпрепознатљивијих обележја старе комедије. У својим парабазама, сам комедиограф иступа као провокатор. Цинични провокатор, који ремети симпозион тако што се потпуно противи његовим правилима, неусаглашен са својом околином, представља фигуру која се најчешће јавља у британском роману. С друге стране, за руску књижевност карактеристичнији су лакрдијаши - Лебедев, Лебјаткин и Фердишченко.

2. Балзак и Достојевски:

изненађујуће беседе и изненађујући догађаји

У слици Тајферове гозбе (Шагринска кожа, 1831) људско тело ступа у нови свет, свет материје и бесконачне друштвене мимикрије. Међутим, свет материје приказан је као свет који има и вишу, егзистенцијалну вредност. Ова представа о телу дата је у комбинацији скандалозних беседа и изненађујућих догађаја. И у једном у другом случају одступања су релативизована. Прво одступање од редоследа догађаја огледа се у томе што главни јунак романа, Рафаел, долази као незвани гост на гозбу богаташа. Друго одступање огледа се у слици потпуног расула којим се гозба завршава - након беседа, гости се препуштају разврату. Одступање од садржаја беседе огледа се у томе што, уместо целовитих беседа, новинари изговарају кратке и ефектне каламбуре у којима се алудира на телесна уживања.

Храни и говору дата је подједнака важност: Тајферови гости говоре $y$ тренутку док испијају вино. Не 
без разлога, описујући ову гозбу Балзак алудира на Раблеов и Петронијев антисимпозион, који садржи три класична елемента: долазак званих гостију, Емила и Рафаела, филозофске беседе и сцену потпуног расула. Наравно, веза између тела, говора и сексуалности код Балзака ни издалека није тако експлицитна као што је на пример код Раблеа. Као код већине писаца 19. века, аспекти сексуалности и телесности код њега остају прећутани и прикривени. У разговорима пијаних филозофира се о телу и о његовој друштвеној функцији. Могућности завођења и освајања друштвеног простора су бесконачне. До успеха се долази преко жена, куртизана, а до жена се, између осталог, долази и употребом језичких и друштвених игара. ${ }^{5}$

Филозофске беседе претворене су у низ наизглед неповезаних филозофских парадокса, чија је функција потпуна релативизација друштвене реалности. ${ }^{6}$ Динамика гротеске, као код Раблеа, изражава раст, увећавање и преобиље животних могућности. ${ }^{7}$ Балзаков текст успоставља свет у којем су могуће бесконачне друштвене мимикрије, и зато је ова слика нешто много више од сатире. Већ смо је анализирали кроз призму друштвених односа. Ваља напоменути да је гротескна

5 О представи релативизације друштвене реалности у роману Шагринска кожа видети Bargues-Rollins, Y., „Une 'danse macabre': du fantastique au grotesque dans la Peau de chagrin", Romantisme 15.48 (1985): 33-46.

6 О функцији филозофских беседа у Балзаковим романима, видети: Borderie, R., „Le corps de la philosophie: 'la peau de chagrin', L’Année balzacienne 2.1 (2001): 199-219.

7 Употребу гротеске у Шагринској кожи веома успешно је анализирала Барг Ролинс Ивон. За разлику од нас, она акценат ставља на елементе фантастике: Bargues-Rollins, Y., „Une 'danse macabre': du fantastique au grotesque dans la Peau de chagrin", Romantisme 15.48 (1985): 33-46. 
природа разговора пијаних повезана са релативизацијом класних односа и обележја. Свака политичка парола изговорена на гозби представља један од углова гледања на историју и њене ћудљиве законе.

Могу се запазити три важне карактеристике које су заједничке за Тајферову и Трималхионову гозбу. Будући да се, као код Петронија Арбитра, на Тајферовој гозби филозофира током теревенке, а не после ње, она представља јасан пример антисимпозиона. У обе гозбене слике дијалози се нагло прекидају паузама у којима се храна уноси и износи. Трећа заједничка црта јесу алузије на позориште - Балзак Тајферову гозбу иронично пореди са класичном трагедијом и дели је на чинове, као позоришну представу (Балзак 1950: 53). „Росинијевским крешендом“ (Ibid., 53) атмосфера Балзакове трагедије тежи све више ка потпуној распојасаности. ${ }^{8}$ Алузије на трагедију и оперу односе се на представу о стабилној структури гозбе и о статичној позицији тела у свет духа. Реч је о пародији: Тајферова гозба, заправо, нема никакву структуру. Догађаји на гозби контекстуализују се као динамика жеље и тренутних потреба.

Главна тема филозофског разговора јесте улазак реалног, људског тела у друштвену и историјску реалност - реалност која пред Рафаелом искрсава у гротескној разноврсности својих мимикрија, позиција и неочекиваних улога. ${ }^{9}$ Тај улазак приказан је као екстатичан догађај: под утицајем попијеног алкохола, новинари би-

8 О Балзаковом односу према музици видети: Parker, D. C., „Balzac, the musician“, The Musical Quarterly 5.2 (1919): 160-168; Glassow, E. T., „Rossini's Mosè According to Balzac Excerpts from Massimilla Doni“, The Opera Quarterly 9.4 (1993): 23-41.

9 Афирмацијом тела и принципа уживања посебно се бавила Бордери Режин. Видети: Borderie, R., „Le corps de la philosophie: 'la peau de chagrin'“, L’Année balzacienne 2.1 (2001): 199-219. 
вају све виспренији и довитљивији, али та „мудрост“, „тешко пијанство које је постало мудро и проницљиво“ изједначено је са празнином и извештаченошћу.

Као што узбуркано море удара о хридине, тако се чинило да ти умови, ношени олујом, желе пољуљати све законе, међу којима плове цивилизације, несвесно се покоравајући вољи Бога, који оставља у природи добро и зло, и чува само за њих тајну вечне борбе. (Балзак 1950: 54)

Обиље гласова и реторички парадокси које новинари изговарају током пијанке умножавају погледе на променљиву слику друштвене стварности. Посебно је интересантно то да се Балзак од ових гласова уопште не дистанцира - ефектни парадокси његовог приповедача претачу се у парадоксе надахнутих новинара.

Између жалосних шала, које су збијали синови Револуције при рођењу једног листа, и разговора весељака, који су пили при рођењу Гаргантуе, зјапио је понор, који је делио 19. век од 16. века. Онај је у смеху припремао рушене, a наш се смеје сред рушевина. ${ }^{10}$ (Балзак 1950: 57)

Постоји немала сличност између последње реченице и обрта којим се, нешто касније, служе банкар и Емил:

Банкар: „Пијмо дакле у част глупе власти која нам даје толику власт над глупанима“ (Ibid., 65).

(...)

Емил: „Кад у законима влада деспотизам, онда у обичајима влада слобода и обрнуто“ (Ibid., 67).

Ове подударности указују на то да сам Балзак учествује у успостављању новог, гротескног света исто-

10 Курзив је наш. 
ријске реалности и да је новинарски говор нешто много више од обичне сатире. Једење и говорење узајамно се не искључују, већ допуњују. Та нова стварност, пуна наизглед нерешивих контрадикција, јесте оно што је у Шагринској кожи најмагичније. ${ }^{11}$ Радосни, раблеовски тон разговора пијаних управо се односи на егзистенцијално разрешавање тих контрадикција. ${ }^{12}$

Главно питање које се поставља јесте: како постићи успех у савременом друштву? Један од одговора је: учествовати у тој мимикрији, прикривати се и прерушавати. Новинари шаљивим тоном оправдавају своје безочне поступке (Балзак 1950: 57-63). Тријумфално се слави бескрупулозно освајање друштвених позиција. Масол је постао републиканац „зато што му је недостајала једна речца испред презимена“; Клод Вињон је усхићен, јер се продао се „за десет новчића“ (Балзак 1950: 55). Управо је та релативност оно што је овде ново и гротескно. Филозофија друштвене динамике потпуно се огледа у динамици језика.

На Тајферовој гозби потпуно доминира импресија расула - уместо филозофских беседа или беседа које одликује озбиљан филозофски дискурс, Балзак описује разговоре пијаних у виду искиданих и кратких реплика. Будући да немају никакву видљиву кохерентност, њихову полифону целину можемо окарактерисати као један од највидљивијих симптома антисимпозиона, онаквог какав налазимо у Петронијевом делу. И са ан-

11 Видети: Fanger, D., Dostoevsky and romantic realism: a study of Dostoevsky in relation to Balzac, Dickens, and Gogol, Northwestern University Press, 1998.

12 О односу између Балзаковог и Раблеовог стваралаштва видети: Lecuyer, M., Balzac et Rabelais, No. 47, Paris, Societe d'edition „Les Belles Lettres“, 1956; Sckommodau, H., „Sens dessus dessous, sens devant derrière bei Balzac und Rabelais", Zeitschrift für romanische Philologie ( $\mathrm{ZrP})$ 84.1-2 (1968): 49-66. 
тичким симпозионом и античким антисимпозионом Тајферова гозба дели одређене наративне и композиционе елементе: долазак незваних гостију, разговори између беседа, и филозофску анализу феномена ероса и љубави, која је овде, као и у Трималхионовој гозби, иронично изједначена са сексуалношћу.

На гротескно јединство трагичног и комичног Балзак сасвим експлицитно алудира тиме што гозбу упоређује са класичном трагедијом и што је, као и трагедију, дели на чинове. Осим пародичне алузије на класично позориште и поетичке полемике између романтичара и класициста, ово поређење сведочи о Балзаковој дубокој уметничкој самосвести и познавању духа античког симпозиона. Као што ћемо имати још прилике да видимо, у симпозиону који приказује Достојевски у роману Идиот - у симпозиону у Лебедевљевом дому, елементи трагичног и комичног готово да су потпуно уравнотежени, премда, у целокупном роману, трагично веома претеже у односу на комично. Насупрот томе, у слици Тајферове гозбе разлике између представа о „трагичном“ и „комичном“ релативизоване су - у разговорима пијаних који се воде између новинара и пропалих писаца, значај историјских трагедија, друштвени преокрети и револуција релативизовани су лаким каламбурима.

Садржај беседа подсећа више на беседе изговорене на Трималхионовој гозби него на беседе изговорене на Платоновој Гозби. ${ }^{13}$ Оне имају још мање садржаја него беседе које приказује Петроније. Међутим, управо та испрекиданост и фрагментарност може се довести у везу са новом филозофијом тела. Каламбур се односи на један тренутак, на телесни гест, а филозофска беседа, с друге стране, односи се на дискурзивно дис-

13 Видети: Woods, Н. А., The Humor of Balzac, 1962. 
танцирање од времена и од представе о томе да тело егзистира и изражава се у времену. Исто тако, као и код Петронија, паузе између „беседа“ немају никакву видљиву структурну улогу. Јер, разговори између беседа подједнако су бесадржајни као и саме беседе. Све то учествује у стварању представе о блиској вези између телесног геста и беседе којима тело само себе изражава.

Ако се не може рећи да је Рафаелово подлегање искушењима богатства приказано као нешто трагично, исто тако се не може рећи да је оно комично. Ово релативизовање омогућено је вештим комбиновањем готске атмосфере са реалним гозбеним амбијентом - реч je, укратко, о једној типичној романтичарској гротески. Гротеска се изграђује делимично и на основу очигледне паралеле између садржаја беседе и понашања гостију - док филозофирају о историји, љубави и магији друштвених односа, новинари „једу и пију“ (Балзак 1950: 55). Дакле, својим понашањем гости потврђују главне идеје изложене у беседама. Ново тело улази у историју, ${ }^{14}$ што значи да употребом гротеске Балзак успоставља један нови уметнички свет.

Улогу Платонове Диотиме на Тајферовој гозби преузимају разуздане куртизане, Аквилина и Еуфразија. Тема њихове беседе је: женска врлина и однос мушкараца према женама. Куртизане Емила и Валентина уче томе како да сексуалност повежу са филозофијом друштвеног опортунизма. Амбициозни мушкарац до успеха долази преко жена.

Аквилина и Еуфразија се у својим беседама подсмевају хришћанским врлинама:

14 О односу између тела и историје видети: Petrey, S., Realism and revolution: Balzac, Stendhal, Zola, and the performances of history, Cornell University Press, 1988; Cooter, R., „The Turn of the Body: History and the Politics of the Corporeal", ARBOR Ciencia, Pensamiento y Cultura 186 (2010): 393-405. 
„Крепост! Ми је препуштамо ружним и грбавим женама“;

„подавати се читавог живота човеку, који је одвратан, одгајати децу која ће те оставити, и још им рећи: хвала, ето то су крепости, које ви захтевате“; „сви су говорили док су јели“ (Балзак 1950: 56).

Све те беседе, ма колико звучале испразно, пред читаоцем, откривају нови свет Људске комедије.

3. Мармеладов и Лебедев: пијанство, расуло и нова рајска хармонија

Још у већој мери него Балзакови, симпозиони у романима Фјодора Михајловича Достојевског одликују се јасним жанровским паралелама са Платоновим симпозионом. Одступање од редоследа догађаја карактерише долазак незваног госта, долазак или затечено присуство чанколиза, или потпуни скандал на крају гозбе. Одступање од предвиђене беседе контекстуализује се увођењем фигуре лика „филозофа будале“, који држи проповед о љубави, као што су Мармеладов и Мишкин, или о темама које се посредно односе на љубав, као што је Лебедев. Релативизовање ова два одступања могуће је повезати са наглашеном драмском структуром његових романа. Они толико прожимају сваки сегмент његовог стваралаштва да је велико питање имамо ли права да уопште говоримо о антисимпозиону, или да можда није боље употребити термин „симпозион““15.

15 О драмској структури романа Фјодора Михајловича Достојевског видети: Шестов, Л., Достоевский и Нитше: философия трагедии, Скифы, 1922; Иванов, В., „Достоевский и роман-трагедия“, Coбp. coч 4 (1881); Cox, R. L., Between earth and heaven: Shakespeare, Dostoevsky, and the meaning of Christian tragedy, Holt McDougal, 1969. 
Тема гозбених разговора у роману Идиот је „спасење света“. Као једна од најзаступљенијих тема у стваралаштву Достојевског, она битно одређује контекст хармоније и расула гозбе. Код њега је ова тема уско повезана са логиком апсурда. ${ }^{16}$ Реторика апсурда је увек обележена логиком искупљења, а разговори пијаних током симпозиона представљају њен веома важан део. Симпозион одражава не само опште црте полифоније о којој говори Бахтин у својој монографији Проблеми

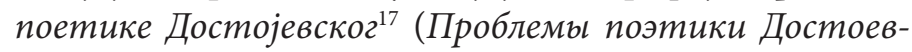
ского, 1963) већ управо и њену најтешњу повезаност са идејом о спасењу света. Лик-идеја долази у сукоб са спољашњом средином, и као последица тога неминовно настаје скандал, а некада се дешава и злочин, који се на крају показује као неопходан елемент спасења и искупљења. Због тога су у гозбеним сликама веома изражени драмски делови и гротескни ликови са гротескним патосом, какви су Мармеладов (Злочин и казна) и Лебедев (Идиот).

У роману Злочин и казна (Преступление и наказание, 1866) Мармеладовљев апокалиптични говор занимљив је највише због тога што сам за себе представља једну малу драму. То није говор пијанца, већ

16 Нажалост, западноевропски критичари имају обичај да апсурд у романима Достојевског повезују са поетиком модернизма. Такав је случај са монографијом Роја Дејвисона, у којој се пореде Достојевски и Ками: Davison, R., Camus: the challenge of Dostoevsky, University of Exeter Press, 1997. Као последица тога, егзистенцијалистичка димензија апсурда углавном се доводи у везу ca атеизмом или чак нихилизмом, што, без сумње, представља веома једностран поглед на стваралаштво Фјодора Михајловича Достојевског.

17 Видети: Бахтин, М., Проблеми Поетике Достојевског, прев. Милица Николић, Београд, 2000. Феноменом полифоније Бахтин се подробно бави у првом поглављу, стр. 7-47. 
разговор пијанца. Иако Раскољников све време током његове беседе ћути, ми чујемо дијалог - заправо, Мармеладов га искушава да учествује у људском разговору који му болно недостаје, којег се одриче, али којем све време несвесно тежи. Код Достојевског патос се јавља у самом злочину, а искупљење у казни. Долазак Раскољникова у крчму само је најава тога драматичног преокрета. Мисао о томе да рационално размишљање доводи до злочина код Достојевског је на изузетан начин повезана са идејом да истовремено и необични и драматични догађаји могу повратити веру у људскост и истински живот. Због тога патос симпозиона увек има егзистенцијалне димензију. За дубоким егзистенцијалним доживљајем заједнице са људима Раскољников несвесно чезне. Он је већ загњурен у „логичка и рационална" размишљања у којима оправдава злочин и убиство старе лихварке.

У крчму он улази као „незвани гост“. У суштини, за сваког посетиоца крчме може се рећи да је незвани гост, али је у тексту експлицитно наглашено да Раскољников крчме ретко посећује. Он све време ишчекује да ће се догодити нешто што је само по себи непредвидиво - да ће наићи на интересантног саговорника. Достојевски се игра речју „жажда“ и тиме отвара питање: чега је то Раскољников жедан, пива или искреног разговора? Мармеладов, можда, нема куда да иде, као што и сам каже на почетку беседе (Достоевский 1975: 40) и зато излаз налази у безумљу, али то безумље се не одражава на његовом телу и лику. Он је јадан и понижен, али управо зато је, у исто време, и велики пророк. Он не само да није бурлескан, него, према логици коју је Достојевски поставио, он и не може постати бурлескан. Сиромаштво није порок, тврди Мармеладов (Ibid., 40). Али то, у исто време, не значи да је пијанство некак- 
ва посебна, романтичарска врлина. Достојевски, у том погледу, остаје до краја реалиста. Мармеладов је гротескан управо зато што га његово пијанство и унижава и узвисује. Он јесте лакрдијаш - трагичан и комичан у исто време. ${ }^{18}$

Мармеладовљев ударац по челу јесте ударац стварног човека. Сасвим је реално то што се обратио Раскољникову: данима ни са ким реч није проговорио. А када је проговорио, рекао је велике истине и о себи и о човечанству. Он је прљав, јадан, понижен човек. Он је, како и сам каже, „свиња“ која ужива у томе што га, са добрим разлогом, бије властита жена (Ibid., 55). То је живо, напаћено тело, које својом великом беседом очовечује и „осмишљава“ светско лудило које са свих страна надолази. А то лудило је лудило разума. Гротескно је и то што патос врхунац достиже у слици свакодневног скандала: у конкретном случају, Катарина Николајевна, схватајући да је Мармеладов пропио сав новац, псује га и вуче за косу, на шта овај узвикује да у томе ужива. То је завршетак драме.

Раскољников је Мармеладова срео изненада, случајно, али ипак имајући предосећај да ће некога срести. Утонуо у мрачне мисли, он у једном тренутку осећа жеђ. Попио би хладно пиво - зато улази у оближњу крчму, у потајној жељи да некога сретне.

Једино текстови Достојевског могу да издрже толики симболички набој а да остану увек сливени са најнепосреднијом реалношћу. Мармеладовљево „безумие“ јесте оно што Достојевски сам тражи у својим текстовима. Мармеладов је „забавник“ (забављач), како га називају гости у крчми (Ibid., 54), али забављач који се

18 Видети: Murav, Н., Holy foolishness: Dostoevsky's novels \& the poetics of cultural critique, Stanford University Press, 1992. 
исповеда и који, исповедајући се, истовремено разуме и прониче у душе других људи.

Позиција Мармеладовљевог тела у свету материје одређује се подједнако на основу изгледа тога тела, односа тела према садржају говора, односно беседи коју изговара и драматској структури догађаја коју његово понашање изводи. Тематско одступање огледа се у чињеници да се узвишена беседа „не очекује“ од обичне пијанице. Оно је релативизовано егзистенцијалним контекстом Раскољниковљевог случајног доласка: оптерећен мрачним мислима, Раскољников губи веру у „живу реч“ - и предаје се логичком, дијалектичком размишљању, који покушава да објективира идеју о убиству и људском телу у апстрактном свету духа. Па ипак, он је подсвесно желео да сретне Мармеладова. Као „забавник“ Мармеладов јесте глумац. Његова „жива“ беседа представља дијалошко побијање хладног интелектуализма. То се исто може рећи и за његово тело: тај глумац је неугледан, смешан, трагикомичан.

То је „безумник“ подједнако жедан разговора као и Раскољников - његов други лик, којег је сиромашни студент предосећао и желео да види. Он јесте театралан, али никада преко мере која би била неприродна. У крчми је Мармеладов приказан као биће које је присутно у свету, ма колико од других био издвојен. На крају - Мармеладов је жив човек. ${ }^{19}$

Око њих двојице чују се песме пијаница и чују се којекакве простачке опаске, на које се пропали чиновник сам надовезује, као на сугестије за смер свога приповедања. Мармеладов је и раније долазио у крчму тражећи публику за своје говоре, али претпостављамо

19 Видети: Gibian, G., „Traditional symbolism in crime and punishment", Publications of the Modern Language Association of America (1955): 979-996. 
- није нашао ниједног човека попут Раскољникова нити је Раскољников, месецима раније, упознао човека налик Мармеладову. Премда сам каже да „ему некуда идти“ (нема куда да иде), он тражи лак излаз у пићу, али, исто тако, у снажном, „истинитом“, душевном говору.

Мармеладовљева беседа позиционира представу о телу у свету духа, контекстуализујући га као тело које се преображава. Неугледно тело пијанице јесте представа која посредује између света духа и света материје. Беседа јуродивог и неугледног човека, која се завршава малим скандалом: на повратку кући његова жена, Катарина Николајевна, сазнавши да је пропио сав новац, почиње да виче на њега вукући га за косу.

У роману Идиот, у опису симпозиона у Павловску (Идиот, 1869), на којем Лебедев држи говор о племенитом људождеру, ситуација је још сложенија. Она садржи сва три композициона елемента, карактеристична за жанр антисимпозиона: долазак незваних гостију (кнез Мишкин), филозофски разговор (Лебедевљева беседа) и догађај који ремети хармонију симпозиона (Иполитово неуспело самоубиство). За разлику од описа сусрета између Раскољникова и Мармеладова, драмска структура је јасна и постоји очигледна паралела између садржаја говора и скандала који му следи. Али, пијани разговори које воде Лебедев, Евгеније Павлович, Гаврило Ардалионович и кнез Мишкин важни су због тога што се у њима потпуно разоткрива патос личности и њихов однос према идеји о спасењу света. Ни у једној другој сцени симпозиона у роману 19. века није постигнут тако широк и тако еластичан распон између трагичног и комичног.

Тема филозофског дијалога јесте спасење света. То је једна од оних тема по којима је Достојевски најпрепо- 
знатљивији као мислилац. Први део расправе није приказан. На основу Лебедевљевих речи, знамо само то да се између њега и Гаврила Ардалионовича, амбициозног адвоката и поборника западних вредности, води дискусија о прогресу човечанства. Не слажући се са идејом о општем добру, које се може статистички израчунати, пијани Лебедев држи беседу о људождеру који је појео шездесет монаха и након свега отишао код католичког свештеника да би се покајао за своје грехе. У 12. веку, током периода глади један људождер је појео шездесет католичких свештеника, и, „само“ шесторо грађанске деце. Јео их је двадесетак година, док је глад трајала, што је, како закључује Лебедев, нешто сасвим логично и природно. На основу тога што је јео само свештенике, а да се грађана није ни дотицао, Лебедев закључује да је свештенство било шездесет пута срећније него дотадашње човечанство, зато што је било шездесет пута гојазније. Људождер, „или његов клијент“, одлази свештенству и исповеда своје грехе - то значи да постоји нека виша мисао, узвишено осећање које је изнад биолошких потреба и нагона (Достојевски 1969: 351).

Док код Балзака новинарски парадокси откривају нови, гротескни свет друштвене стварности, дотле Лебедевљева гротеска открива једну метафизичку димензију и тежи управо ка томе да надиђе и обезвреди логику етичке релативности. За Лебедевљеве парадоксе можемо наћи многе паралеле у Шагринској кожи, али њихова сврха је потпуно другачија.

На пример, његова реченица да „богатства има више, али снаге има све мање“ (Достојевски 1969: 352) подсећа на Емилову идеју о богатству беде и беди богатства (Балзак 1950: 49). Али Лебедевљева порука потпуно се разликује од Емилове: он говори о штетном утицају богатства на људско егзистенцијално разуме- 
вање морала. Парадокс је управо у томе што је он сам, као властелин, веома имућан човек. Он сам се смеје томе што његови гости једу и пију док расправљају о општем добру.

С друге стране, циничне парадоксе сличне овима изговарају западњаци и атеисти, на првом месту Иполит и Гаврило Ардалионович. Гаврило Ардалионович je разгаљен пићем, али и даље размишља логично. Смејући се Лебедевљевој причи, он додаје: „Сигурно је да су се само монаси у 18. веку, могли јести, јер су само монаси могли бити угојени“ (Достојевски 1969: 76). Јасно је да је Достојевском атмосфера гозбе била потребна да своју идеју о спасењу света стави у контекст свакодневице. Пијанство је овде својеврстан експеримент, у којем се супротставља пијанство логичара и пијанство безумника. Разговори пијаних служе томе да у исто време на драматичан и на непосредан начин разоткрију унутрашњу природу књижевних ликова. ${ }^{20}$

Гозба у Павловску садржи све главне композиционе црте хеленског симпозиона: долазак незваних гостију, Мишкина и Рогожина, филозофске беседе и скандал, који, ма колико био озбиљан - реч је о Иполитовом неуспелом самоубиству - ни у једном једином тренутку не оставља утисак потпуног расула. Упркос тако великом скандалу, хармонија симпозиона није поремећена. Осим тога, убачени су и разговори између беседа који се преплићу са прекидањима и изазивањима упућеним Иполиту. Иван Фјодорович најдуже коментарише Ле-

20 Видети: Ivask, G., „Dostoevsky’s Wit“, Russian Review (1962): 154164; Anderson, R., „The Idiot and the Subtext of Modern Materialism“, Dostoevsky Studies 9 (1988): 77-89. О комичним аспектима ове гозбене слике видети: Givens, J., „A narrow escape into faith? Dostoevsky's Idiot and the Christology of Comedy", The Russian Review 70.1 (2011): 95-117. 
бедевљеву, а Јевгеније Павлович Иполитову беседу.

Трагикомична кулминација гозбе указује на то да је Достојевски несвесно следио жанровску конвенцију симпозиона која захтева да се друштвене и филозофске тензије релативизују. Однос између садржаја беседа и контекста учествује видљиво у стварању гротескног израза. Тема обе беседе - Лебедевљеве и Иполитове односи се на материјалистичко схватање људског живота и међуљудских односа. Прва беседа блиска је ренесансној, а друга модернистичкој гротески. Прву беседу држи пијани лакрдијаш, а други трезвени болесник. Али, врло је битно то што се обе беседе о „материјализму“ држе у свету у којем је материја веома присутна у виду хране и пића. Док се једе и пије, Лебедев говори о људождеру који прождире монахе и води статистику о његовим жртвама. С друге стране, Иполитова главна дилема јесте то да ли ће умрети сам, поред Мајеровог зида, или међу људима - исто тако, у атмосфери у којој се једе, пије и смеје. Трагично и комично се овде тако дубоко прожимају да је једно немогуће разлучити од другог. Та симбиоза огледа се и у односу публике према двема беседама.

Беседу Лебедева лакрдијаша публика схвата донекле озбиљно, а беседу Иполита, трагичног јунака, већина присутних, осим Вере, Лебедевљеве ћерке, не узима озбиљно, јер нико не верује да ће се он заиста убити. Премда је Лебедевљева беседа пуна лакрдије и гротеске, Јепанчин му критички замера на томе што на крају предлаже закуску - као да је заиста од Лебедева очекивао некакву озбиљну проповед (Достојевски 1969: 356). Улога Иполита подсећа на улогу незваног госта у античкој гозби. Његово тело је присутно на гозби, али то присуство релативизовано је чињеницом да он умире од туберкулозе. Позиција његовог тела у свету 
материје нестабилна је и илузорна: и представа о његовом умирању и нестајању је релативизована, будући да се његова смрт све до самога краја романа одлаже. Уз то, скандал који он прави на гозби представља само пародију скандала - одступање од уобичајеног редоследа догађаја не изазива потпуно расуло, већ је приказано као очекивани део гозбе. Његова смрт се све време очекује. Али, у егзистенцијалном смислу, смрт не може да се „догоди“: и када је очекивана, она је изненађење.

\section{Извори и литература}

Ames, K. L. Death in the dining room and other tales of Victorian culture. Temple University Press, 1995

Балзак, Оноре де. Шагринска кожа. Загреб, 1961.

Dover, K. J. „Aristophanes' Speech in Plato's Symposium“. The Journal of Hellenic Studies 86 (1966): 41-50.

Достојевски, Ф. М. Идиот. Београд

Saxonhouse, A. W. „The Net of Hephaestus: Aristophanes' Speech in Plato's Symposium“. Interpretation. A Journal of Political Philosophy Flushing, NY 13.1 (1985): 15-32

Ludwig, Paul W. „Politics and Eros in Aristophanes' Speech: Symposium 191e-192a and the Comedies“. American journal of philology (1996): 537-562.

Видети: Sider, D. „Plato's Symposium as Dionysian Festival“, Quaderni urbinati di cultura classica (1980): 41-56; Salman, C., "Anthropogony and Theogony in Plato's Symposium“, Classical Journal (1991): 214-225 
Pavle Pavlović

\section{MEMORY OF THE GENRE OF SYMPOSION IN THE 19. CENTURY NOVEL}

Our paper analyzes the legacy of symposion in the 19.century novel. The main thesis is that banquet imagery determines the position of the body in relation to the world of matter and the world of the Other. As a framework for our analysis we take the text of Plato's Symposion and Bakhtin's idea of „the memory of genre". The basic idea is that in a banquet imagery two sets of rules are relativized: the rules that define „serious“ speech and the rules that embody predictable patterns of events. The positioning of the body in the world of matter is defined as burlesque, whereas the ambivalent positioning - „between" the world of matter and the the world of the OTHER - is defined as grotesque. In light of these considerations, we analyze the grotesque and burlesque aspect of the banqet imagery from Balzac's novel Le Peau du Chagrin, Dostoevsky's novel Idiot and Crime and Punishment, Gogol's Dead Souls. 